\title{
The Importance of Computerized Analysis on Spoilage of Sweet Orange (Citrus Sinensis), Before Harvest and Carriage to Market, in Nigeria
}

\author{
Prince Awojoodu Soji \\ Department of Computer Science and Mathematics, Oduduwa University, Osun State, Nigeria
}

Email address:

awojoodusoji@yahoo.com

\section{To cite this article:}

Prince Awojoodu Soji. The Importance of Computerized Analysis on Spoilage of Sweet Orange (Citrus Sinensis), Before Harvest and Carriage to Market, in Nigeria. International Journal of Astrophysics and Space Science. Vol. 7, No. 6, 2019, pp. 66-74.

doi: $10.11648 /$ j.ijass.20190706.12

Received: June 21, 2019; Accepted: August 12, 2019; Published: December 4, 2019

\begin{abstract}
This research work was carried out, to find the importance of computerized analysis on spoilage of sweet orange, before harvest and carriage to market in Nigeria. 4 Local governments, namely: (Ife East, Ife South, Ife Central and Ife North), local government areas were sampled. 3,200 open questionnaires were distributed to the 4 Local Governments, out of which 800 was used for farmers in each local government. A total of 32 different locations were visited and sampled in all the four Local Governments, out of which 100 questionnaires were used in each location. It was gathered that above $75 \%$ of the people supported that, the computerized analysis on spoilage of sweet orange, before harvest and carriage to market in Nigeria, was important, while less than $25 \%$ of the people, could not even understand whether there was any need, for the importance of computerized analysis on spoilage of sweet orange, before harvest and carriage to market in Nigeria or mot. The results from the questionnaires when using Pearson one-tailed correlation coefficient, however revealed that there was no significant difference from all the farmers visited and sampled, $[\mathrm{p}<0.01]$ and $[\mathrm{p}<0.05]$ table 5 . This shows a strong positive correlation, which implying that, the importance of computerized analysis on spoilage of sweet orange, before harvest and carriage to market in Nigeria, is strongly influenced and enhanced farmer's support, from the four local government areas, visited and sampled, in Ile-Ife Kingdom of Osun State, and Nigeria in general, and therefore had made the research work to become a reality, $[\mathrm{p}<0.01]$ and $[\mathrm{p}<0.05]$, table 5 respectively. The reasons may be due to the fact that, sweet oranges are not only, an excellent source and very rich in vitamin $\mathrm{C}$, folic acid; it is also as a good source of dietary fiber, containing a host of other important nutrient element like: folate, thiamine, niacin, phosphorus, magnesium and copper. They are a good source of B vitamins including vitamin B1, pantothene acid and folate as well as vitamin A, calcium, copper and potassium and are also known to be fat free, sodium free and cholesterol free. Histogram with curve was used to depict the summary data of each of the local government areas sampled.
\end{abstract}

Keywords: Sweet Orange (Citrus Sinensis), Harvest, Spoilage, 4 Local Governments, Osun State, Pearson Correlation

\section{Introduction}

Sweet Orange (citrus sinensis), the fruit of the citrus species, in the family Rutaceae (US National Institute of Health). It is widely rated as the most planted fruit in Nigeria. In Nigeria, this orange is grown in any part of the country as the climatic conditions in the country has proven to be suitable for its growth. About 930,000 tons of citrus fruits are produced annually from an estimated 3 million hectares of land. Sweet oranges are an excellent source and very rich in vitamin $\mathrm{C}$, folic acid and it is also as a good source of dietary fiber, containing a host of other important nutrient element like: folate, thiamine, niacin, phosphorus, magnesium and copper, [1]. They are a good source of B vitamins including vitamin B1, pantothene acid and folate as well as vitamin A, calcium, copper and potassium. Sweet oranges are also known to be fat free, sodium free and cholesterol free. Citrus species are grown for the juice of their fruits. It is also called sweet orange to distinguished it from the related (citrus avoantium), referred to as bitter orange. The sweet orange 
reproduces asexually, varieties of sweet orange arise through mutatirus, [2]. Sweet oranges are one of the most popular fruits around the world. While they are delightful as a snack, or as a recipe ingredient, for many Americans; it is their juice that most associated with good health, having a reputation for being an integral part of a healthy breakfast. Sweet oranges are round citrus fruits with finely, textured skins, that are having colour like pulpy flesh, usually range from about two to three inches in diameter, [3]. Oranges are classified into two general categories: Sweet and bitter. Sweet oranges, being the type most commonly consumed. The popular varieties of the sweet orange (citrus sinensis), include Valencia, Navel and Jaffa oranges, as well as blood orange, a hybrid species that is smaller in size, more aromatic in flavour and has red hues running throughout its flesh. Bitter oranges (citrus aurantium), are often times used to make jam or marmalade, and their zest serves as the flavouring for ligueurs, such as Grand mamier and cointreau, [4].

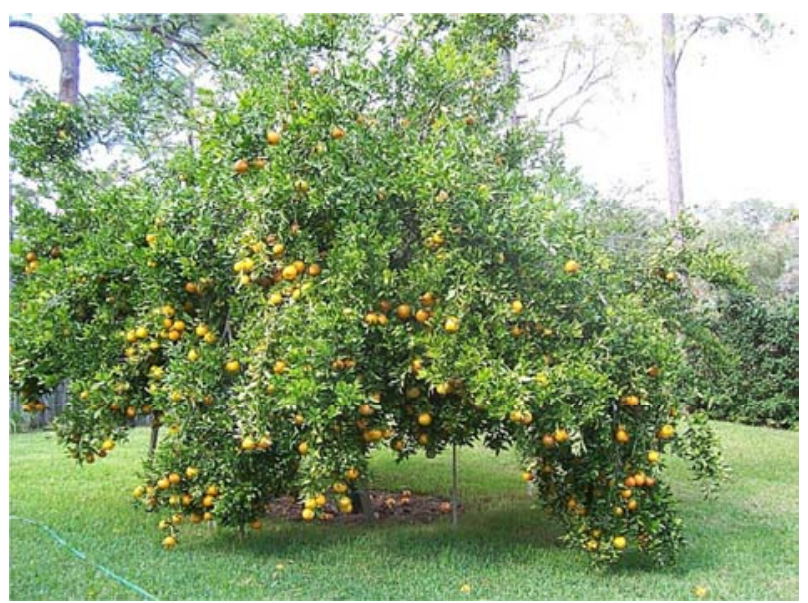

Figure 1. Sweet Orange (citrus sinensis), the fruit of the citrus species, in the family Rutaceae.

\section{ORANGE HISTORY/ORIGIN:}

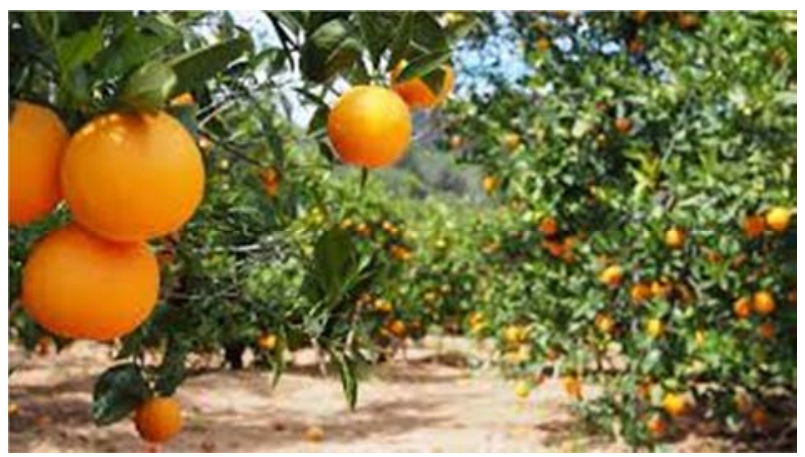

Figure 2. Orange, History/Origin.

Oranges originated thousands of year ago in Asia, in the region from Southern China to Indonecia from which they spread to India. Sweet oranges were introduced into Europe around the $16^{\text {th }}$ century by various groups including the moors and the Portuguese, as well as the Italian traders, and explorers who found them on their voyages to Asia and the middle East. Sweet oranges trees began to be grown in the
Caribbean Islands in the late $15^{\text {th }}$ century after Christopher Columbus brought the seeds there on his second voyage to the new world. Spanish explorers are responsible for bringing oranges to Florida in the $16^{\text {th }}$ century, while Spanish Missionaries brought them to Califonia in the $18^{\text {th }}$ century, beginning the cultivation of this citrus fruit in the two states widely known for their oranges, [5].

YEARS OF MATURITY OF SWEET ORANGE (citrus sinensis) IN NIGERIA:

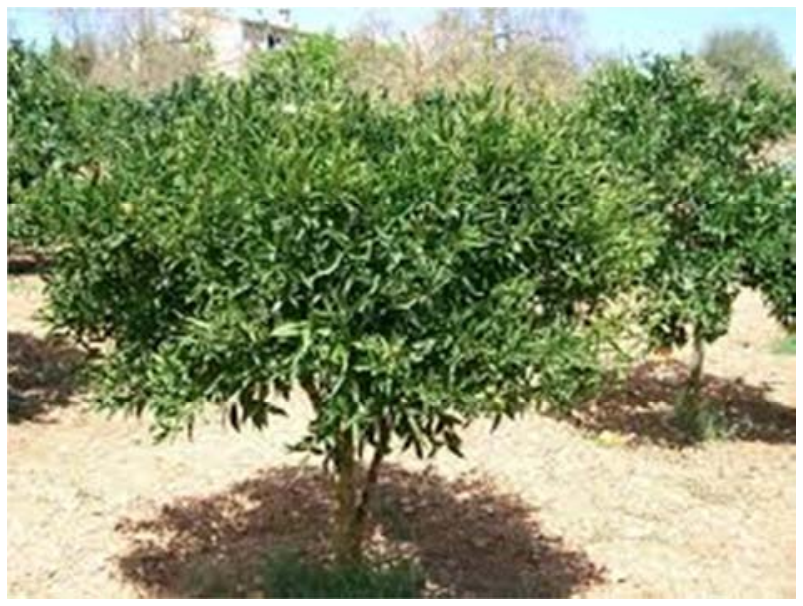

Figure 3. Sweet Orange, years of maturity.

Sweet orange matures very fast. Between $3-4$ years, after planting. In the Southern Nigeria, Oranges are generally available from May/October, with seasonal variation depending on variety. After well grown, it became a seasonal and perishable fruits and goods for consumption both for the buyers and the people.

SWEET ORANGE (citrus sinensis), SPOILAGE BEFORE HARVEST AND CARRIAGE:

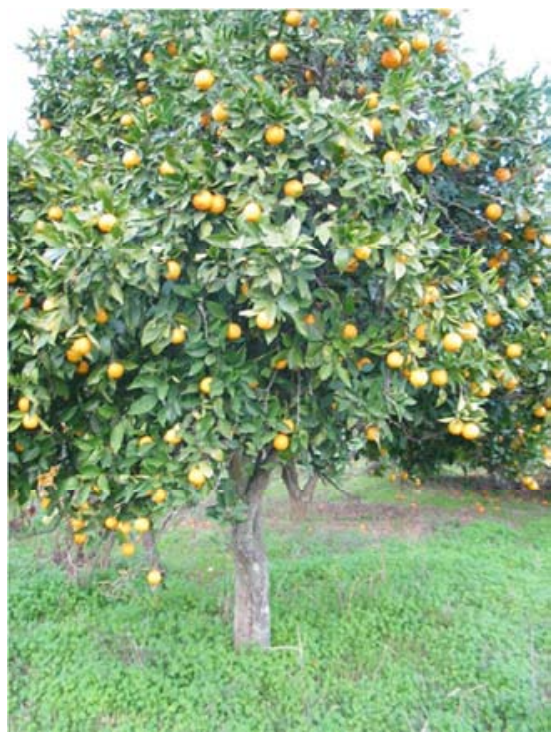

Figure 4. Sweet Orange, risks involved in spoilage before harvesting and carriage to market.

In order to maintain high quality of sweet oranges, for both short term and long term harvest and carriage to Market, 
there are some risks involved concerning spoilage before harvesting and carrying them. This is because, in Nigeria, sweet orange is extremely sensitive to issue of pest and disease, infection, premature fruits drop due to attack by nocturnal fruit piercing moths, termite damage to stern bark and tree roots and gummosis as well as death of budded seedlings.

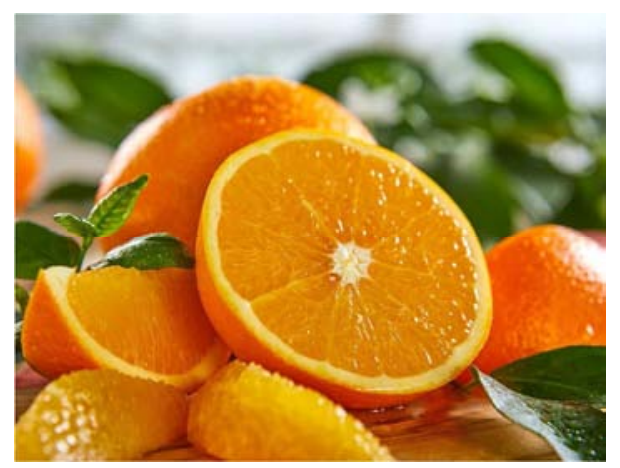

Figure 5. Sweet Orange, spoilage before harvest and carriage to market.

The sweet orange fruits are usually prone to spoilage due to the bad roads and long hours of travel, before reaching the nearby markets, which is also caused by bad roads. The spoilage, in-turns, always lead to great loss for both the farmers and the buyers.

Most of the problems which affects sweet orange production in Nigeria is that, a significant percentage of the product are spoilt or denatured before getting to the consumer markets. Also, some pests and disease of the orange crop can easily spread from one tree to the other if not tacked on time and most times causes reduction in productivity.

SWEET ORANGE (citrus sinensis), CARRIAGE TO MARKET:

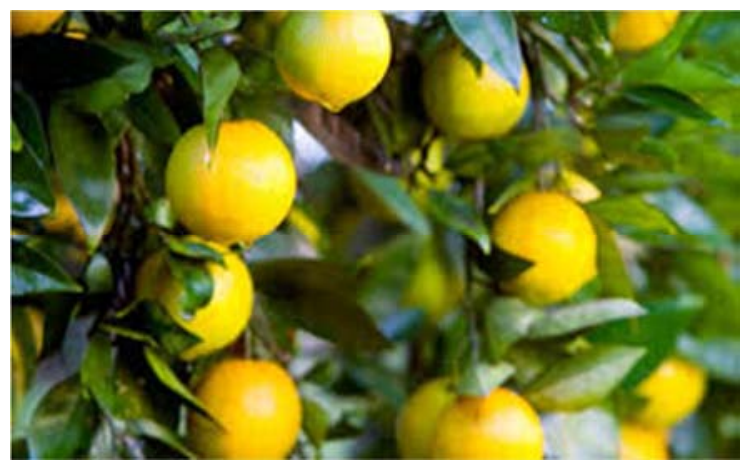

Figure 6. Sweet Orange, harvest and carriage to market.

In Nigeria, the major markets for this fruit are basically made up of two categories: the fresh fruits Market,(since the fresh fruits are majorly perishable and not durable). And the processed fruits Market, (where electro-mechanical devices/machines is used for changing such raw materials into finished goods for the consumers). The major producing States for Sweet Oranges are: Oyo, Ogun, Osun, Kogi, Nassarawa, Bennue, Ebonyi, Kaduna, Taraba, Ekiti, Imo, Kwara, Edo, and Delta.

\section{Material and Methods}

The responses of the farmers in different locations of the four local government areas can be seen from the decision table as below:

Table 1. The Decision Table.

\begin{tabular}{llc}
\hline Sub & Above 75\% & Below 25\% \\
\hline $\begin{array}{l}\text { Computerized Analysis on spoilage of sweet orange before harvest and } \\
\text { carriage to market is important in Nigeria. }\end{array}$ & $\mathrm{X}$ & $\mathrm{X}$ \\
$\begin{array}{l}\text { I do not know } \\
\text { State open questionnaires }\end{array}$ & $\mathrm{X}$ \\
\hline
\end{tabular}

The below are the points ticked by the majority of the people (above 75\% table 1) from the questionnaires who understood and supported, the importance of computerized analysis on spoilage of sweet orange, before harvest and carriage to market in Nigeria.

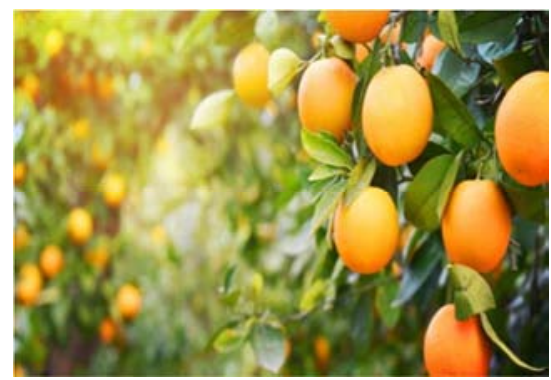

Figure 7. Sweet Orange, and its importance.

[a]. In Nigeria, Sweet Oranges can be eaten in its raw form. [b]. sweet oranges are low in calories and full of nutrients. [c].
It can be used to produce fruit juice and other end products like: frozen concentrates, fragrant peels, pectin, flavours etc. [d]. Vitamin $\mathrm{C}$ in oranges contain fiber, potassium and choline, all of which are good for your heart. [e]. It helps to lower our risk for many diseases. [f]. Sweet oranges are a healthy source of fiber that may help lower blood sugar levels. [g]. Fiber also aids in digestion and may help lower cholesterol by blocking the absorption of cholesterol into the blood stream. [h]. Potassium, an electrolyte mineral, is vital for healthy functioning of the nervours systems. [i]. Lack of potassium can lead to an irregular heart beat (arrhythmia). [j]. Lack of potassium can lead to increased blood pressure. [k]. Lack of potassium can lead to a depletion of calcium in bones. [1]. Potassium found in sweet oranges help to lower pressure, thereby protecting the human body against stroke. [m]. Too much of potassium can lead to hyperkalemia. [n]. Sweet oranges are high in folate, a B vitamin.. [o]. A B vitamin in orange helps the body to lower level of 
homocysteine, an amino acid that is common in red meat and is linked with poor heart health. [p]. Sweet orange promotes clear, and healthy skin. [q]. Most citrus fruits have a good deal of vitamin C. [r]. Vitamin C, a potent antioxidant, that protects cells by scavenging and neutralizing harmful free radicals. [s]. The vitamin $\mathrm{C}$ in sweet oranges may boost a person's immunity to everyday viruses and infections. [t]. The vitamin $\mathrm{C}$ in sweet oranges is associated with a reduced risk of colon cancer, due to preventing DNA mutations from taking place. This shows that, about 10 to 15 percent of colon cancers have a mutation in a gene called BRAF.

\section{Case Study Area}

The study has been conducted in Nigeria. It is located in the West of Africa on the Gulf of guinea and has a total of $923,768 \mathrm{~km}^{2}$ (356.669 square mile), making it the world's $32^{\text {nd }}-$ largest country (after Tanzania). It is comparable in size to Venezuela, and is about twice the size of California. It shares a 4.047 kilometres (2.515 square mile), border with Benin (773 km.), Niger (1497 km.), Chad (87 km.), Cameroon $(1690 \mathrm{~km}$.), and has a coastline of at least $853 \mathrm{~km}$. [51]. Nigeria lies between latitude $4^{\circ}$ and $14^{\circ} \mathrm{N}$, and longitude $2^{\circ}$ and $15^{\circ} \mathrm{E}$ (Encyclopaedia Britannica).

Nigeria is a densely populated country with the highest density of 477.0 /square mile. As at a (2012) estimate, the country held a population of more than 168.8 million people up from the 140 million recorded in her (2006) population census (World Bank Nigeria Data (2012)). Of this population, about 87 million people (52\%) dwell in rural areas while 81 million dwell in urban areas (Trading Economics Rural Population Chart (2012)). The Male/Female ratio is 1: 05, where male commands $51.21 \%$, while females, $48.79 \%$ (Nigerian Census, (2006)).

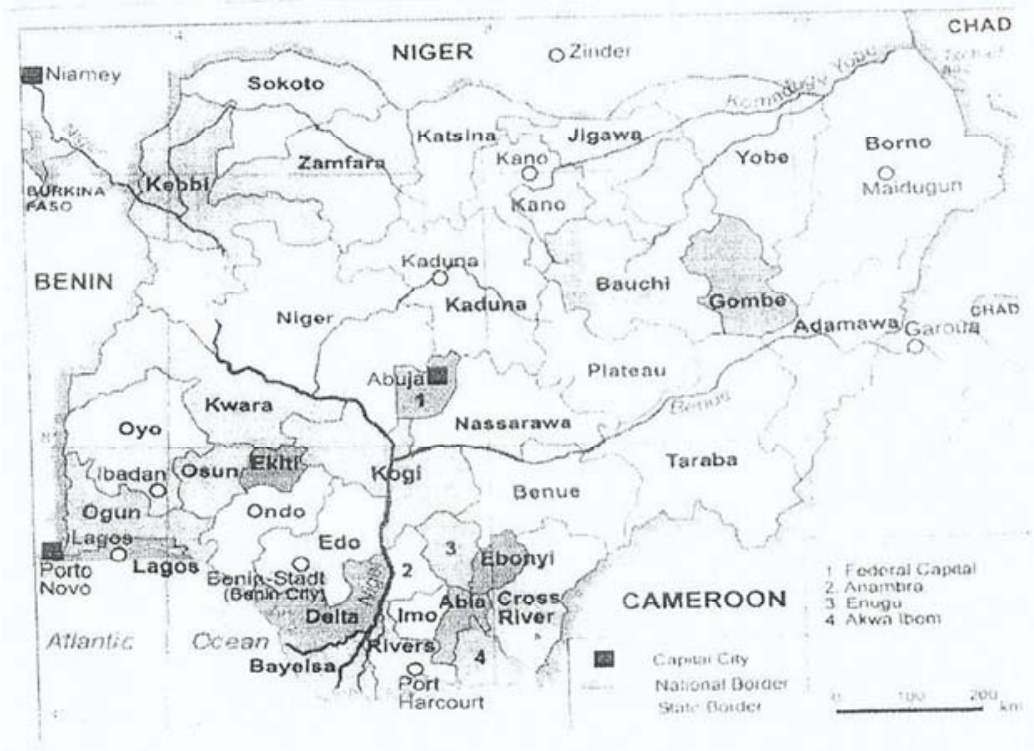

Figure 8. The Study Area Map of Nigeria.

\section{Results and Discussion}

Questionnaires were distributed to 4 Local government areas that is, (Ife East, Ife South, Ife Central and Ife North). The results from the questionnaires however revealed that, the importance of computerized analysis on spoilage of sweet orange, before harvest and carriage to market in Nigeria, are manifold:

There was no significant difference on the people in all the local government areas visited, $[\mathrm{p}<0.01]$ and $[\mathrm{p}<0.05]$.

Table 2. People's respondent.

\begin{tabular}{|c|c|c|c|c|c|c|c|c|}
\hline Wards & Ife East & & Ife South & & Ife Central & & Ife North & \\
\hline $\begin{array}{l}\text { People's } \\
\text { Response }\end{array}$ & $\begin{array}{l}\text { The importance of } \\
\text { computerized } \\
\text { analysis on spoilage } \\
\text { of sweet orange, } \\
\text { before harvest and } \\
\text { carriage to market in } \\
\text { Nigeria. }\end{array}$ & $\begin{array}{l}\text { I do not } \\
\text { know }\end{array}$ & $\begin{array}{l}\text { The importance of } \\
\text { computerized } \\
\text { analysis on spoilage } \\
\text { of sweet orange, } \\
\text { before harvest and } \\
\text { carriage to market in } \\
\text { Nigeria. }\end{array}$ & $\begin{array}{l}\text { I do not } \\
\text { know }\end{array}$ & $\begin{array}{l}\text { The importance of } \\
\text { computerized } \\
\text { analysis on spoilage } \\
\text { of sweet orange, } \\
\text { before harvest and } \\
\text { carriage to market in } \\
\text { Nigeria. }\end{array}$ & $\begin{array}{l}\text { I do } \\
\text { not } \\
\text { know }\end{array}$ & $\begin{array}{l}\text { The importance of } \\
\text { computerized analysis } \\
\text { on spoilage of sweet } \\
\text { orange, before harvest } \\
\text { and carriage to market } \\
\text { in Nigeria. }\end{array}$ & $\begin{array}{l}\text { I do } \\
\text { not } \\
\text { know }\end{array}$ \\
\hline
\end{tabular}


From the above table 2, in Ife East, there are 568 people's response with $71.0 \%$, Ife South, 554 with $69.3 \%$, Ife Central, 557 with $69.6 \%$, and Ife North, 552 with $69.0 \%$, were those People who supported that, the computerized analysis on spoilage of sweet orange, before harvest and carriage to market in Nigeria was important., while in Ife East, 232 with
$29.0 \%$, Ife South, 246 with $30.7 \%$, Ife Central, 243 with $30.4 \%$, and Ife North, 248 with $31.0 \%$ respectively, could not even know whether there was any need or not for the computerized analysis on spoilage of sweet orange, before harvest and carriage to market in Nigeria.

Table 3. The different locations and local governments, also the summary data collected, from the 4 Local Governments sampled, out of which 800 were used in each local government.

\begin{tabular}{|c|c|c|c|c|c|c|c|c|c|}
\hline \multirow[t]{2}{*}{ LOCAL GOVERNMENT } & \multirow{2}{*}{$\begin{array}{l}\text { LOCATION } \\
\text { A }\end{array}$} & \multicolumn{2}{|c|}{ IFE EAST } & \multicolumn{2}{|c|}{ IFE SOUTH } & \multicolumn{2}{|c|}{ IFE CENTRAL } & \multicolumn{2}{|c|}{ IFE NORTH } \\
\hline & & 71 & 29 & 68 & 32 & 75 & 25 & 68 & 32 \\
\hline \multirow{7}{*}{ Peoples Respondent } & $\mathrm{B}$ & 77 & 23 & 72 & 28 & 73 & 27 & 79 & 21 \\
\hline & $\mathrm{C}$ & 69 & 31 & 79 & 21 & 78 & 22 & 74 & 26 \\
\hline & $\mathrm{D}$ & 75 & 25 & 64 & 36 & 62 & 38 & 65 & 35 \\
\hline & $\mathrm{E}$ & 62 & 38 & 60 & 40 & 59 & 41 & 62 & 38 \\
\hline & $\mathrm{F}$ & 72 & 28 & 70 & 30 & 69 & 31 & 70 & 30 \\
\hline & G & 68 & 32 & 69 & 31 & 70 & 30 & 64 & 36 \\
\hline & $\mathrm{H}$ & 74 & 26 & 72 & 28 & 71 & 29 & 70 & 30 \\
\hline TOTAL $=$ & 8 & 568 & 232 & 554 & 246 & 557 & 243 & 552 & 248 \\
\hline Grand Total $=$ & 8 & 800 & & 800 & & 800 & & 800 & \\
\hline
\end{tabular}

Table 4. The descriptive statistics.

\begin{tabular}{llll}
\hline Descriptive Statistics & & & \\
\hline & Mean & Std. Deviation & N \\
\hline IFEEAST & 71.0000 & 4.72077 & 8 \\
IFESOUTH & 69.2500 & 5.67576 & 8 \\
IFECENTRAL & 69.6250 & 6.36817 & 8 \\
IFENORTH & 69.0000 & 5.58058 & 8 \\
\hline
\end{tabular}

Correlations

Table 5. The Pearson Correlation of the 4 local governments.

\begin{tabular}{llllll}
\hline Correlations & & & & & \\
\hline & & IFEEAST & IFESOUTH & IFECENTRAL & IFENORTH \\
\hline \multirow{5}{*}{ IFEEAST } & Pearson Correlation & 1 & .368 & .337 & $.629^{*}$ \\
& Sig. (1-tailed) & & .185 & .207 & .047 \\
& Sum of Squares and Cross-products & 156.000 & 69.000 & 71.000 & 116.000 \\
& Covariance & 22.286 & 9.857 & 10.143 & 16.571 \\
& N & 8 & 8 & 8 & 8 \\
& Pearson Correlation & .368 & 1 & $.892^{* *}$ & $.758^{*}$ \\
& Sig. (1-tailed) & .185 & & .001 & .015 \\
& Sum of Squares and Cross-products & 69.000 & 225.500 & 225.750 & 168.000 \\
& Covariance & 9.857 & 32.214 & 32.250 & 24.000 \\
& N & 8 & 8 & 8 & 8 \\
& Pearson Correlation & .337 & $.892^{* *}$ & 1 & $.699^{*}$ \\
& Sig. (1-tailed) & .207 & .001 & & .027 \\
& Sum of Squares and Cross-products & 71.000 & 225.750 & 283.875 & 174.000 \\
& Covariance & 10.143 & 32.250 & 40.554 & 24.857 \\
& N & 8 & 8 & 8 & 8 \\
& Pearson Correlation & $.629^{*}$ & $.758^{*}$ & $.699^{*}$ & 1 \\
& Sig. (1-tailed) & .047 & .015 & .027 & 174.000 \\
& Sum of Squares and Cross-products & 116.000 & 168.000 & 24.857 \\
\hline
\end{tabular}

*. Correlation is significant at the 0.05 level (1-tailed).

**. Correlation is significant at the 0.01 level (1-tailed). 
Table 6. The Frequency Table of (Ife East, Ife South, Ife Central, and Ife North) including the mean, mode std. deviation of the 4 local government areas. FREQUENCIES VARIABLES=IFEEAST IFESOUTH IFECENTRAL IFENORTH.

/NTILES $=4$.

/NTILES=10.

/STATISTICS=STDDEV VARIANCE RANGE MINIMUM MAXIMUM SEMEAN MEAN MEDIAN MODE SUM SKEWNESS SESKEW.

KURTOSIS SEKURT.

/GROUPED=IFEEAST IFESOUTH IFECENTRAL IFENORTH.

/HISTOGRAM NORMAL.

/ORDER=ANALYSIS.

\begin{tabular}{|c|c|c|c|c|c|}
\hline Statistics & & & & & \\
\hline & & IFEEAST & IFESOUTH & IFECENTRAL & IFENORTH \\
\hline \multirow{2}{*}{$\mathrm{N}$} & Valid & 8 & 8 & 8 & 8 \\
\hline & Missing & 0 & 0 & 0 & 0 \\
\hline \multicolumn{2}{|l|}{ Mean } & 71.0000 & 69.2500 & 69.6250 & 69.0000 \\
\hline \multicolumn{2}{|l|}{ Std. Error of Mean } & 1.66905 & 2.00669 & 2.25149 & 1.97303 \\
\hline \multicolumn{2}{|l|}{ Median } & $71.5000^{\mathrm{a}}$ & $69.5000^{\mathrm{a}}$ & $70.5000^{\mathrm{a}}$ & $68.6667^{\mathrm{a}}$ \\
\hline \multicolumn{2}{|l|}{ Mode } & $62.00^{\mathrm{b}}$ & 72.00 & $59.00^{\mathrm{b}}$ & 70.00 \\
\hline \multicolumn{2}{|l|}{ Std. Deviation } & 4.72077 & 5.67576 & 6.36817 & 5.58058 \\
\hline \multicolumn{2}{|l|}{ Variance } & 22.286 & 32.214 & 40.554 & 31.143 \\
\hline \multicolumn{2}{|l|}{ Skewness } & -.826 & .032 & -.634 & .651 \\
\hline \multicolumn{2}{|l|}{ Std. Error of Skewness } & .752 & .752 & .752 & .752 \\
\hline \multicolumn{2}{|l|}{ Kurtosis } & .824 & .794 & -.311 & .017 \\
\hline \multicolumn{2}{|l|}{ Std. Error of Kurtosis } & 1.481 & 1.481 & 1.481 & 1.481 \\
\hline \multicolumn{2}{|l|}{ Range } & 15.00 & 19.00 & 19.00 & 17.00 \\
\hline \multicolumn{2}{|l|}{ Minimum } & 62.00 & 60.00 & 59.00 & 62.00 \\
\hline \multicolumn{2}{|l|}{ Maximum } & 77.00 & 79.00 & 78.00 & 79.00 \\
\hline \multicolumn{2}{|l|}{ Sum } & 568.00 & 554.00 & 557.00 & 552.00 \\
\hline \multirow{11}{*}{ Percentiles } & 10 & $63.8000^{\mathrm{c}}$ & $61.2000^{\mathrm{c}}$ & $59.9000^{\mathrm{c}}$ & $62.6000^{\mathrm{c}}$ \\
\hline & 20 & 68.1000 & 64.4000 & 62.7000 & 64.1000 \\
\hline & 25 & 68.5000 & 66.0000 & 65.5000 & 64.5000 \\
\hline & 30 & 68.9000 & 67.6000 & 68.3000 & 64.9000 \\
\hline & 40 & 70.4000 & 68.7000 & 69.7000 & 67.1000 \\
\hline & 50 & 71.5000 & 69.5000 & 70.5000 & 68.6667 \\
\hline & 60 & 72.6000 & 70.4000 & 71.6000 & 69.7333 \\
\hline & 70 & 74.1000 & 71.4667 & 73.2000 & 71.6000 \\
\hline & 75 & 74.5000 & 72.0000 & 74.0000 & 72.6667 \\
\hline & 80 & 74.9000 & 73.8667 & 74.8000 & 73.7333 \\
\hline & 90 & 76.4000 & 77.6000 & 77.1000 & 77.5000 \\
\hline
\end{tabular}

a. Calculated from grouped data.

b. Multiple modes exist. The smallest value is shown.

c. Percentiles are calculated from grouped data.

Tables $(7,8,9$, and 10) The frequency Tables for (Ife East, Ife South, Ife Central and Ife North).

Table 7. Valid and cumulative percentages of Ife East.

\begin{tabular}{|c|c|c|c|c|c|}
\hline \multicolumn{6}{|c|}{ IFEEAST } \\
\hline & & Frequency & Percent & Valid Percent & Cumulative Percent \\
\hline \multirow{9}{*}{ Valid } & 62.00 & 1 & 12.5 & 12.5 & 12.5 \\
\hline & 68.00 & 1 & 12.5 & 12.5 & 25.0 \\
\hline & 69.00 & 1 & 12.5 & 12.5 & 37.5 \\
\hline & 71.00 & 1 & 12.5 & 12.5 & 50.0 \\
\hline & 72.00 & 1 & 12.5 & 12.5 & 62.5 \\
\hline & 74.00 & 1 & 12.5 & 12.5 & 75.0 \\
\hline & 75.00 & 1 & 12.5 & 12.5 & 87.5 \\
\hline & 77.00 & 1 & 12.5 & 12.5 & 100.0 \\
\hline & Total & 8 & 100.0 & 100.0 & \\
\hline
\end{tabular}


Table 8. Valid and cumulative percentages of Ife South.

\begin{tabular}{|c|c|c|c|c|c|}
\hline \multicolumn{6}{|c|}{ IFESOUTH } \\
\hline & & Frequency & Percent & Valid Percent & Cumulative Percent \\
\hline \multirow{8}{*}{ Valid } & 60.00 & 1 & 12.5 & 12.5 & 12.5 \\
\hline & 64.00 & 1 & 12.5 & 12.5 & 25.0 \\
\hline & 68.00 & 1 & 12.5 & 12.5 & 37.5 \\
\hline & 69.00 & 1 & 12.5 & 12.5 & 50.0 \\
\hline & 70.00 & 1 & 12.5 & 12.5 & 62.5 \\
\hline & 72.00 & 2 & 25.0 & 25.0 & 87.5 \\
\hline & 79.00 & 1 & 12.5 & 12.5 & 100.0 \\
\hline & Total & 8 & 100.0 & 100.0 & \\
\hline
\end{tabular}

Table 9. Valid and cumulative percentages of Ife Central.

\begin{tabular}{|c|c|c|c|c|c|}
\hline \multicolumn{6}{|c|}{ IFECENTRAL } \\
\hline & & Frequency & Percent & Valid Percent & Cumulative Percent \\
\hline \multirow{9}{*}{ Valid } & 59.00 & 1 & 12.5 & 12.5 & 12.5 \\
\hline & 62.00 & 1 & 12.5 & 12.5 & 25.0 \\
\hline & 69.00 & 1 & 12.5 & 12.5 & 37.5 \\
\hline & 70.00 & 1 & 12.5 & 12.5 & 50.0 \\
\hline & 71.00 & 1 & 12.5 & 12.5 & 62.5 \\
\hline & 73.00 & 1 & 12.5 & 12.5 & 75.0 \\
\hline & 75.00 & 1 & 12.5 & 12.5 & 87.5 \\
\hline & 78.00 & 1 & 12.5 & 12.5 & 100.0 \\
\hline & Total & 8 & 100.0 & 100.0 & \\
\hline
\end{tabular}

Table 10. Valid and cumulative percentages of Ife North.

\begin{tabular}{|c|c|c|c|c|c|}
\hline \multicolumn{6}{|c|}{ IFENORTH } \\
\hline & & Frequency & Percent & Valid Percent & Cumulative Percent \\
\hline \multirow{8}{*}{ Valid } & 62.00 & 1 & 12.5 & 12.5 & 12.5 \\
\hline & 64.00 & 1 & 12.5 & 12.5 & 25.0 \\
\hline & 65.00 & 1 & 12.5 & 12.5 & 37.5 \\
\hline & 68.00 & 1 & 12.5 & 12.5 & 50.0 \\
\hline & 70.00 & 2 & 25.0 & 25.0 & 75.0 \\
\hline & 74.00 & 1 & 12.5 & 12.5 & 87.5 \\
\hline & 79.00 & 1 & 12.5 & 12.5 & 100.0 \\
\hline & Total & 8 & 100.0 & 100.0 & \\
\hline
\end{tabular}

Figures: $(9,10,11$, and 12). The Histogram with Curve, the rate of observations or occurrences) from the data for (Ife East, Ife South, Ife Central and Ife North).

\section{Histogram}

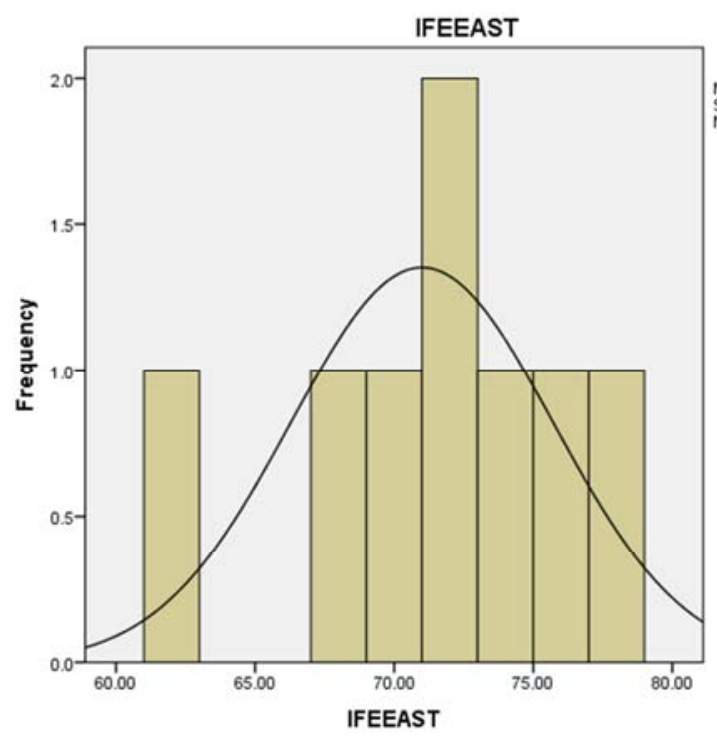

Figure 9. The Histogram with Curve of Ife East.

The vertical coordinates represent the frequency (that is, analysis while the horizontal coordinates represent the range from the valid data in Table 7, (that is, based on 1 unit interval as $[60,65,70,75,80]$, respectively.

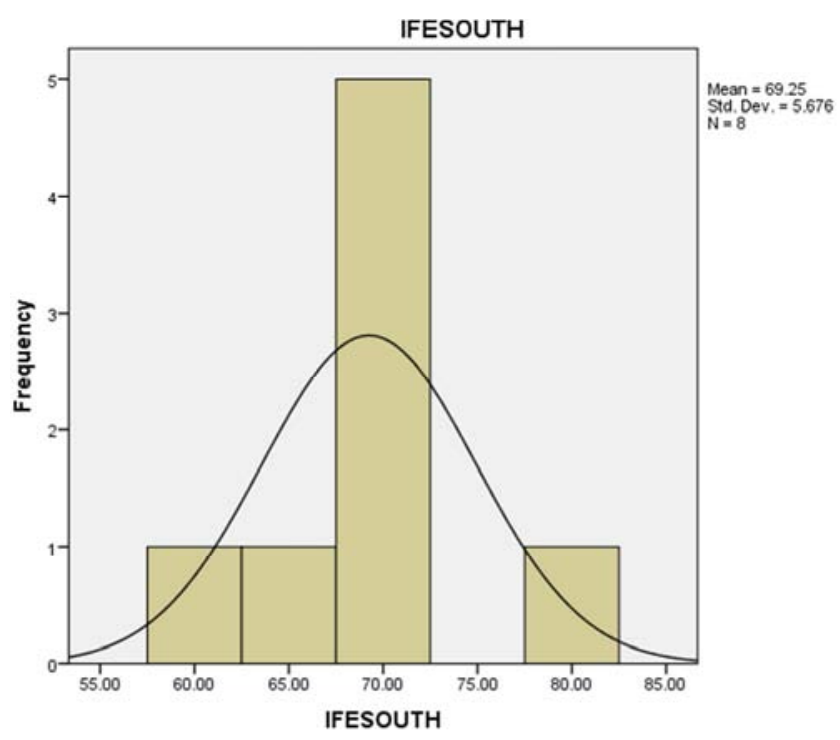

Figure 10. The Histogram with Curve of Ife South. 
The vertical coordinates represent the frequency (that is, the rate of observations or occurrences) from the data analysis while the horizontal coordinates represent the range from the valid data in Table 8, (that is, based on 1 unit interval as $[55,60,65,70,75,80,85]$, respectively.

The vertical coordinates represent the frequency (that is, the rate of observations or occurrences) from the data analysis while the horizontal coordinates represent the range from the valid data in Table 9, (that is, based on 1 unit interval as $[55,60,65,70,75,80,85]$, respectively.

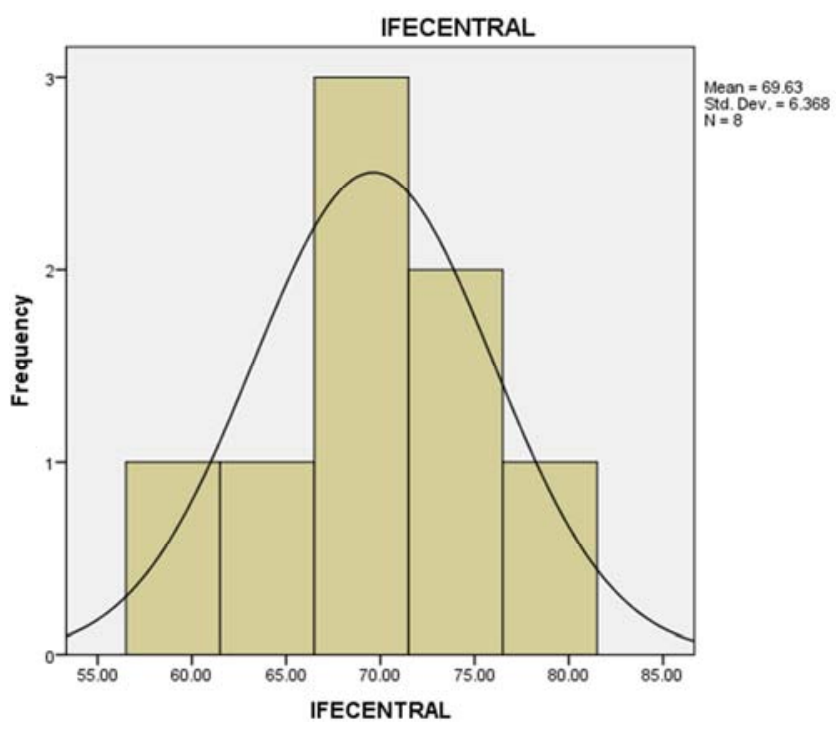

Figure 11. The Histogram with Curve of Ife Central.

Figure 5 The histogram of Ife North.

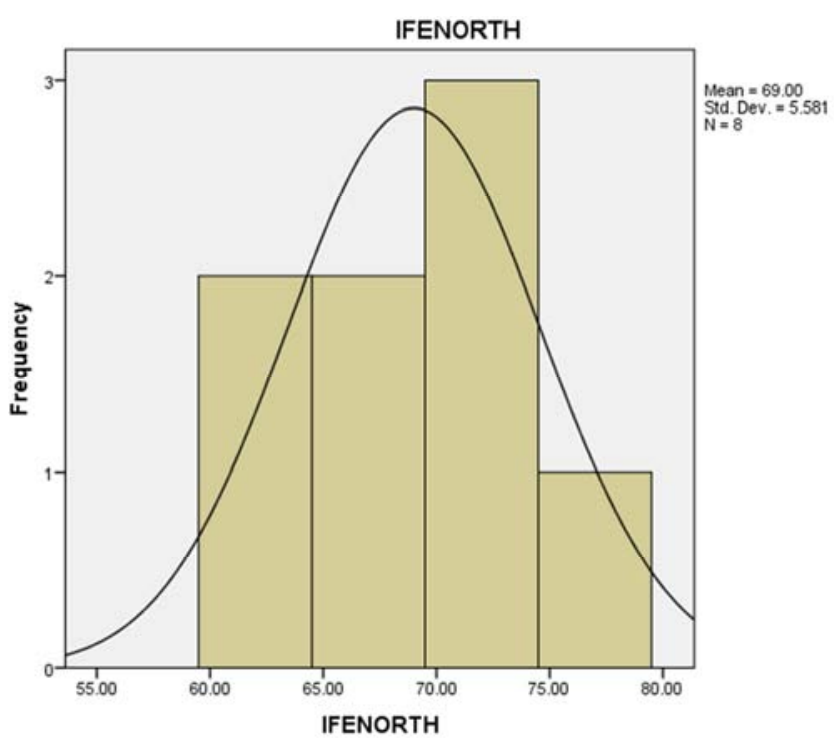

Figure 12. The Histogram with Curve of Ife North.

The vertical coordinates represent the frequency (that is, the rate of observations or occurrences) from the data analysis while the horizontal coordinates represent the range from the valid data in Table 10, (that is, based on 1 unit interval as $[55,60,65,70,75$, and 80$]$, respectively.

\section{Recommendations}

1. Nigerian Government should encourage sweet orange plantation, by given funds/loans to prospective investors 2 . Federal government should support the farmers by given enough assistance in terms of seedlings subsidy, so as to booth their production 3. Workshop at different intervals should be organised to farmers, so as to educate them in the uses of current farmer's equipments, to increase their sweet orange output production and eradicate sweet orange spoilage. 4. Some of the rural areas roads in, Nigeria, are bad. Government should provide good motor-able roads to farmers in plantation areas with high concentration of sweet orange farm. 5. Government should provide electricity in rural areas for Farmers to enable them to stay longer in their farm for maximum increase in their sweet orange harvest Production. 6. Government should organised Agricultural extension services to farmers by providing and bringing agricultural equipments closer to them, so as to reduce the cost of sweet orange harvest to the buyers. 7. Government should erect large storage facilities at intervals for sweet orange farmers, to avoid losses and spoilage. 8. For high Productivity and ultimate high investment, The Federal Government of Nigeria should encouraged sweet orange farmers to make research and seek expert opinion and advice for the latest productivity techniques to maximize profit.

\section{Conclusion}

The following conclusions are made based on the findings of this study. Since sweet oranges are an excellent source and very rich in vitamin $\mathrm{C}$, folic acid and it is also as a good source of dietary fiber, containing a host of other important nutrient element for human health, like: folate, thiamine, niacin, phosphorus, magnesium and copper; the results of this study provide the empirical evidence that the importance of computerized analysis on spoilage of sweet orange, before harvest and carriage to market in Nigeria, had enhanced people's achievement in our society and in Nigeria at large. The society, therefore should use, the importance of computerized analysis on spoilage of sweet orange, before harvest and carriage to market in Nigeria's techniques, to argument peoples' maximal output in businesses, in order to attain minimum goal needed for everybody in the society.

\section{Acknowledgements}

The Author wishes to express his appreciations to all especially those whose papers that are shown in my references to provide the premise for this study, and Dr. / Chief Ramond Adedoyin, (The ATOBATELE, MAYE of Yoruba Kingdom), The Chancellor and Founder of Oduduwa University for providing the fund and space to carry out this research work / study. 


\section{References}

[1] Aderinlewo E. O., 1982. Basic Secondary Science Book 1. Published by Evans Brothers Limited. Montague House, Russell square London WC1B5BX. Composition in 11 on 13 point century by Film type services Limited, Scarborough, North Yorkshire and Printed by William Clowes (Beccles) Limited, Beccles and London ISBN 0237505274. NPR 1137.

[2] Ashutosh Kar, 2011. Advanced Practical Chemistry. First Edition. Printed in India at Saras Graphics, Rai, Haryana. Typeset at Goswami Associates, Delhi. Publishing for one world New Age International (P) Limited, Publishers. 4835/24, Ansari Road, Daryaganj, New Delhi-110002. ISBN (0): $81-224-$ 1539 - 9. ISBN (13): $978-81-224-1539-1$.

[3] Dr. Tilak Ram, 2013. Food Chemistry. Published in India by Random Publications. 4376-A/4B. Gall Murari Lai, Ansari Road, New Delhi - 110002. Typesetting by: Friends Media, Delhi -110087 . Digitally Printed at: Replica Press Pvt. Ltd. ISBN $978-93-5111-032-3$.

[4] Elservier, E. [2009. Guide to Protein Purification. 2nd Edition. Academic Press. 525B street, suite 1900. San Diego, a 92101 - 4495, USA, 30 corporate Drive. Suite 400, Burlington, MA 01803, USA. 32 Jamestown Road, London. NW1 7BY, UK. ISBN: $978-0-12-374536-1$ (hardback). ISBN: $978-0-$ $12-374978-9$ (paper back). ISSN: 0076-6879.

[5] Fan Y. Ding Z. Yang L. et al. A Prelimnary Study on Bioactivity of Orange and Tangerine Peal extracts against Apluis and mites. Zhongguo Zhong Yao Za Zhi 1995 Jul: 20 (7): 397-8, 446. 1995. PMID: 13090.

[6] George Coulouris, Jean Dollimore and Tim Kindberg, 2011. Distributed Systems, Concepts and Design, 4th Edition. Published by Dorling Kindersley [India] Pvt. Ltd. Licensees of Pearson Education in South Asia. HeadOffice: 7th floor, Knowledge Bouleward. A-8 [A], Sector-62. Noida-201309, U. P. India Registered Office: 11Community Centre, Panchsheel Park. New Delhi110017, India. Printed in India by Manipal Press Ltd. ISBN 978-81-317-1840-7. Authorized adaptation from the United Kingdom Edition, Entitled Distributed System Concepts and Design. Forth Edition, ISBN: 9780321263544 by Coulouris, George: Dollimore, Jean; Kindberg, Tim; Published by Education, Ltd. Copyright @ 2005. Indian Subcontinent Adaptation copyright@ 2009 Dorling Kindersley [India] Pvt. Ltd.

[7] Gordon M. Wardlaw, 2003. Contemporary Nutrition Issues and Insight. Fifth Edition. Published by McGraw - hill, a business unit of McGraw - Hill Companies, Inc., 1221 avenue of the Americas, New York, NY 10020. ISBN: $0-07-$ $286530-\mathrm{X}$. ISBN: $0-07-119903-\mathrm{X}(15 \mathrm{E})$. International Edition. ISBN: $0-07-118808-\mathrm{X}$.

[8] Honow R., Laube N. Schneider A, Kessier T. Hesser. Influence of grape fruit, Orange, and apple juice consumption on urinary variables and risk of crystallization. Br. Intr. Aug: 90 (2) 295-300.2003. PMID: 12908889.
[9] Jill Norman, 1997. The Classic Herb Cook Book. First published in Great Britain by Dorling Kindersley Limited. 9, Henrietta Street, London WC2E8PS. Reprint in 1997. A CIP for this book is available from the British Library. ISBN: 0751303232. Reproduced in Italy by Scanner Service SRL. Printed and bound in Italy by a Monadori, Veronica.

[10] John R. Holum, 1975. Experiments in General Organic and Biological Chemistry. A laboratory Manual, Forth Edition. New York. London. Sydney. Toronto. Printed in the United State of America. 10987654321.

[11] Kumar R., 1984. Insect Pest Control. First Published in Great Britain. Printed and bound in Great Britain by Atheneum Press Ltd. Gateshead British Library Cataloguing in Publication Data. ISBN 0713180838. Member of the Holder Headline Group. 338 Euston Road, London WW1 3BH.

[12] Melvin Calvin and J. A Bassham 1962. The Photosynthesis of Carbon Compounds. Library of Congress Catalogue Card Number: $62-10567$. Manufactured in the United States of America. The Manuscripts was received November 15, 1961, and Published February 27, 1962. W. A. Benjamin, Inc. 2465 Broadway, New York 25, New York.

[13] Nyle C. Brandy, 1990. The nature and Properties of Soils. Printed in the United State of America by Mac Millian Publishing Company. Simon \& Schuster A. Viacon Company, Upper Saddle River, New Jersey, 074p58. ISBN 0-13-852444-0.

[14] O. P. Agarwal, 2014. Organic Chemistry, Natural Products Volume - 1. Published by: Satyendra Rostogi, "mitra" for KRISHNA Prakasha media (P) Ltd. 11, Shivaji Road, Meerut - 25001 (U. P.) India. Printed at Majmoon Press, Meerut. Typing: DEBUG CC. (The computer concern) Ghaziabad, ISBN: $978-81-8283-556-6$.

[15] Rai H., 2004. Basic Industrial Biochemistry. Printed in India at Ramprintograph, Delhi. Typeset at In-house. Publishing for one world. New Age International (P) limited. Publishers. 4835/24, Ansari Road, Daryaganj, New Delhi-110002. ISBN: $978-81-224-3404-0\}$.295 . C $-12-04-6261$.

[16] Rapisarda P. Tomaino A. Lo Cascio R., et al. Antroxidant effectiveness as influenced by Phenolic content of fresh orange juices. J, Agric Food Chem. 1999 Nov: 47 (11): 471823-.1999. PMID: 13080.

[17] S. K. Jain, 2001. Mineral Processing. For CBS Publishers and Distributors Pvt. Ltd. CBS Plaza, 4819/XI Prahlad Street, 24 Ansari Road, Daryaganj, New Delhi - 110002, India. Ph: 23289259, 232668861, 23266867. ISBN: $81-239-0753-2$.

[18] Tilak Wasan, 2015. Solid Waste Pollution and Health. Published at Arisari Road, 4383/4B, Darga Ganj. New Delhi110002 (India). ISBN: 978 - 93 - 5056 - 306 - 9. Discovery Publishing House PVT. Ltd. Printed at: Infinity Imaging Systems Delhi. 